\title{
Monogenic Human Obesity Syndromes
}

\author{
I.S. FAROOQI AND S. O'RAHILLY \\ Department of Clinical Biochemistry, University of Cambridge, Addenbrooke's Hospital, \\ Cambridge CB2 2QQ, United Kingdom
}

\begin{abstract}
Over the past decade, we have witnessed a major increase in the scale of scientific activity devoted to the study of energy balance and obesity. This explosion of interest has, to a large extent, been driven by the identification of genes responsible for murine obesity syndromes and the novel physiological pathways revealed by those genetic discoveries. We and others recently have identified several single-gene defects causing severe human obesity. Many of these defects have occurred in molecules identical or similar to those identified as a cause of obesity in rodents. This chapter will consider the human monogenic obesity syndromes that have been characterized to date and discuss how far such observations support the physiological role of these molecules in the regulation of human body weight and neuroendocrine function.
\end{abstract}

\section{Introduction}

The concept that mammalian body fat mass is likely to be regulated has its underpinning in experimental science going back over 50 years. The adipostatic theory of Kennedy (1953), which emerged in the 1950s, was based on his observations of responses of rodents to perturbations of food intake, together with the hypothalamic lesioning studies of Hetherington (Hetherington and Ranson, 1940) and Anand (Anand and Brobeck, 1951) and the parabiosis experiments of Hervey (1959). The subsequent emergence of several murine genetic models of obesity (Bray and York, 1971) and their study in parabiosis experiments by Coleman (1973) led to the consolidation of the concept that a circulating factor might be involved in mediation of energy homeostasis. However, it was not until the 1990s, when the precise molecular basis for the agouti, $o b / o b, d b / d b$, and fat/fat mouse emerged, that the molecular components of an energy balance regulatory network began to be pieced together (Leibel et al., 1997). The use of gene-targeting technology has gone on to demonstrate the critical roles of certain other key molecules in that network, such as the melanocortin 4 receptor (MC4R) (Huszar et al., 1997) and melanin-concentrating hormone (MCH) (Shimada et al., 1998; Chen et al., 2002).

409

Copyright $(92004$ by The Endocrine Society All rights of reproduction in any form reserved. 
A critical question raised by these discoveries is the extent to which these regulatory pathways are operating to control human body weight. Over the past few years, a number of novel monogenic disorders causing human obesity have emerged (Barsh et al., 2000). In many cases, the mutations are found in components of the regulatory pathways identified in rodents. The importance of these human studies is several-fold. First, they established for the first time that humans can become obese due to a simple inherited defect. Second, it has been notable that in all cases, the principle effect of the genetic mutation has been to disrupt mechanisms regulating food intake. Third, some defects, though rare, are amenable to rational therapy. Fourth, although the physiological consequences of mutations in the same gene in humans and mice are frequently very similar, there are certain key interspecies differences in phenotype.

This review will describe certain recent advances in our understanding of single-gene defects causing human obesity. It will not consider genetic diseases such as Bardet-Biedl, Cohen's, Alstrom's, and Prader-Willi, where obesity is only one feature in a complex developmental disorder. Indeed, considerable advances have been made in the identification of genetic defects underlying many of these syndromes. However, in all cases, the link between the molecular defect and the clinical phenotype remains unclear (reviewed in O'Rahilly and Farooqi, "The Genetics of Obesity in Humans," at www.endotext.org.).

\section{Congenital Leptin Deficiency}

In 1997, we reported two severely obese cousins from a highly consanguineous family of Pakistani origin (Montague et al., 1997). Both children had undetectable levels of serum leptin and were found to be homozygous for a frameshift mutation in the $o b$ gene $(\Delta \mathrm{G} 133)$, which resulted in a truncated protein that was not secreted (Montague et al., 1997; Rau et al., 1999). We since have identified three more affected individuals from two other families (Farooqi et al., 2002; I.S. Farooqi and S. O'Rahilly, unpublished observations) who are homozygous for the same mutation in the leptin gene. All the families are of Pakistani origin but are not known to be related over five generations. A large Turkish family who carries a homozygous missense mutation also has been described (Strobel et al., 1998). All subjects in these families are characterised by severe, early-onset obesity and intense hyperphagia (Farooqi et al., 1999,2002; Ozata et al., 1999). Hyperinsulinaemia and an advanced bone age are also common features (Farooqi et al., 1999,2002). Some of the Turkish subjects are adults with hypogonadotropic hypogonadism (Ozata et al., 1999). Although normal pubertal development did not occur, there was some evidence of a delayed but spontaneous pubertal development in one person (Ozata et al., 1999).

We demonstrated that children with leptin deficiency had profound abnormalities of T-cell number and function (Farooqi et al., 2002), consistent with 
high rates of childhood infection and a high reported rate of childhood mortality from infection in obese Turkish subjects (Ozata et al., 1999). Most of these phenotypes closely parallel those seen in murine leptin deficiency (Table I). However, some phenotypes do not have as clear-cut parallels between human and mouse. Thus, while ob/ob mice are stunted (Dubuc and Carlisle, 1988), it appears that growth retardation is not a feature of human leptin deficiency (Farooqi et al., $1999,2002)$, although abnormalities of dynamic growth hormone (GH) secretion have been reported in one human subject (Ozata et al., 1999). ob/ob mice have marked activation of the hypothalamic-pituitary-adrenal axis, with very elevated corticosterone levels (Dubuc, 1977). In humans, abnormalities of cortisol secretion are, if present, much more subtle (Farooqi et al., 2002). The contribution of reduced energy expenditure to the obesity of the $o b / o b$ mouse is reasonably well established (Trayhurn et al., 1977). In leptin-deficient humans, we found no detectable changes in resting or free-living energy expenditure (Farooqi et al., 2002), although it was not possible to examine how such systems adapted to stressors such as cold. Ozata and colleagues reported abnormalities of sympathetic nerve function in leptin-deficient humans, consistent with defects in the efferent sympathetic limb of thermogenesis (Ozata et al., 1999).

\section{Response to Leptin Therapy}

Recently, we reported the dramatic and beneficial effects of daily subcutaneous injections of leptin for reducing body weight and fat mass in three congenitally leptin-deficient children (Farooqi et al., 2002). We have commenced therapy in two other children and seen comparably beneficial results (I.S. Farooqi and S. O'Rahilly, personal observations). All children showed a response to initial leptin doses that were designed to produce plasma leptin levels at only $10 \%$ of those predicted by height and weight (i.e., $\approx 0.01 \mathrm{mg} / \mathrm{kg}$ of lean body mass) (Farooqi et al., 2002). The most-dramatic example of leptin's effects was in a 3-year-old boy, severely disabled by gross obesity (weight, $42 \mathrm{~kg}$ ), who now weighs $32 \mathrm{~kg}$ (75th centile for weight) after 48 months of leptin therapy (Figure 1).

The major effect of leptin was on appetite, with normalisation of hyperphagia. Leptin therapy reduced energy intake during an 18-megajoule (MJ) ad libitum test meal by up to $84 \%$ (5 MJ ingested pretreatment vs $0.8 \mathrm{MJ}$ post-treatment in the child with the greatest response) (Farooqi et al., 2002). We were unable to demonstrate a major effect of leptin on basal metabolic rate or free-living energy expenditure (Farooqi et al., 2002). However, as weight loss by other means is associated with a decrease in basal metabolic rate (BMR) (Rosenbaum et al., 2002), the fact that energy expenditure did not fall in our leptin-deficient subjects is notable. 
TABLE I

Phenotypes Associated with Leptin Deficiency in Rodents (ob/ob) and Humans

\begin{tabular}{|c|c|c|}
\hline Phenotype & $o b / o b$ & Human leptin deficiency \\
\hline Total body weight & $3 \mathrm{X}$ Normal & Mean BMI sds $=6.2$ \\
\hline \multicolumn{3}{|l|}{ Body composition } \\
\hline Fat mass & $>50 \%$ & Mean $57 \%$ of body weight \\
\hline Lean mass & Decreased & Normal for age \\
\hline Bone mineral content & Decreased & Normal for age \\
\hline Food intake & Increased meal size & $\begin{array}{l}\text { Increased meal size and } \\
\text { frequency }\end{array}$ \\
\hline \multicolumn{3}{|l|}{ Energy expenditure } \\
\hline Body temperature & Decreased in response to cold & Normal in basal state \\
\hline Basal metabolic rate & Decreased oxygen consumption & $\begin{array}{l}\text { Appropriate for body } \\
\text { composition }\end{array}$ \\
\hline Physical activity & Reduced & Reduced \\
\hline SNS activation & $\begin{array}{l}\text { Basal decreased and refractory to } \\
\text { cold exposure }\end{array}$ & Reduced in response to cold \\
\hline \multicolumn{3}{|l|}{ Metabolic responses } \\
\hline Diabetes & Fasting hyperglycaemia & Normoglycaemia \\
\hline Hyperinsulinaemia & $\begin{array}{l}\text { Severe; resistance to exogenous } \\
\text { insulin }\end{array}$ & $\begin{array}{l}\text { Appropriate for degree of } \\
\text { obesity }\end{array}$ \\
\hline $\begin{array}{l}\text { T cell-mediated } \\
\text { immunity }\end{array}$ & $\begin{array}{l}\text { Decreased CD4 cells, reduced T-cell } \\
\text { proliferation }\end{array}$ & $\begin{array}{l}\text { Decreased CD4 cells, reduced } \\
\text { T-cell proliferation }\end{array}$ \\
\hline \multicolumn{3}{|l|}{$\begin{array}{l}\text { Neuroendocrine } \\
\text { function }\end{array}$} \\
\hline Reproductive & Hypogonadotropic hypogonadism & $\begin{array}{l}\text { Hypogonadotropic } \\
\text { hypogonadism }\end{array}$ \\
\hline Thyroid & $\begin{array}{l}\text { Hypothalamic and ?peripheral } \\
\text { effects }\end{array}$ & $\begin{array}{l}\text { Mild hypothalamic } \\
\text { hypothyroidism }\end{array}$ \\
\hline Growth & Stunted & $\begin{array}{l}\text { Normal linear growth and } \\
\text { IGF-1 levels }\end{array}$ \\
\hline Adrenal & Corticosterone excess & $\begin{array}{l}\text { Normal cortisol and ACTH } \\
\text { levels }\end{array}$ \\
\hline
\end{tabular}

[Abbreviations: BMI, body mass index; SNS, sympathetic nervous system; IGF-1, insulin-like growth factor-1; ACTH, corticotropin.] 


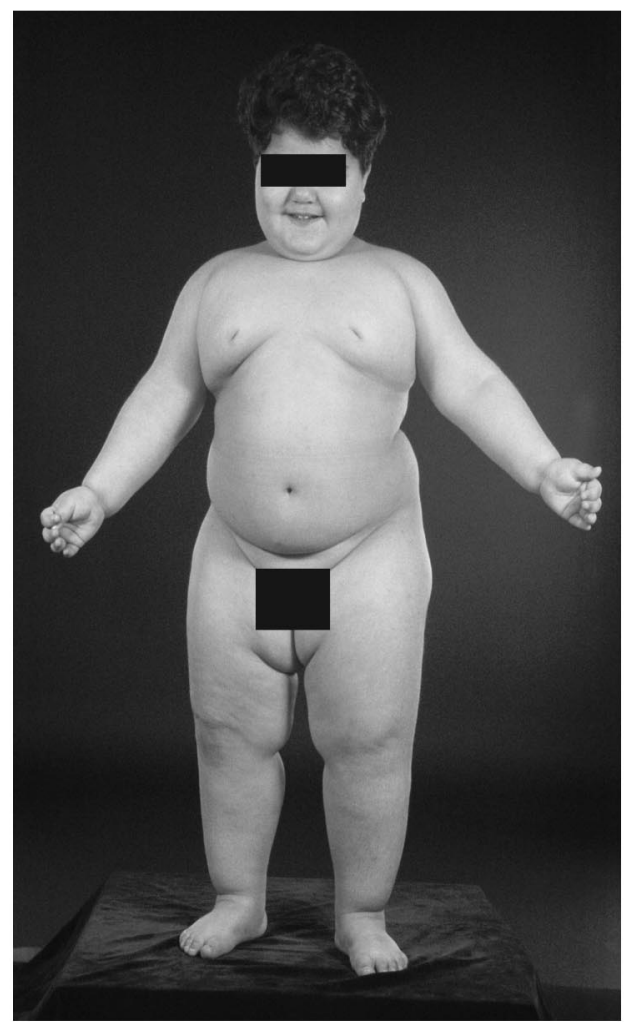

$3 y r$ old weighing $42 \mathrm{~kg}$

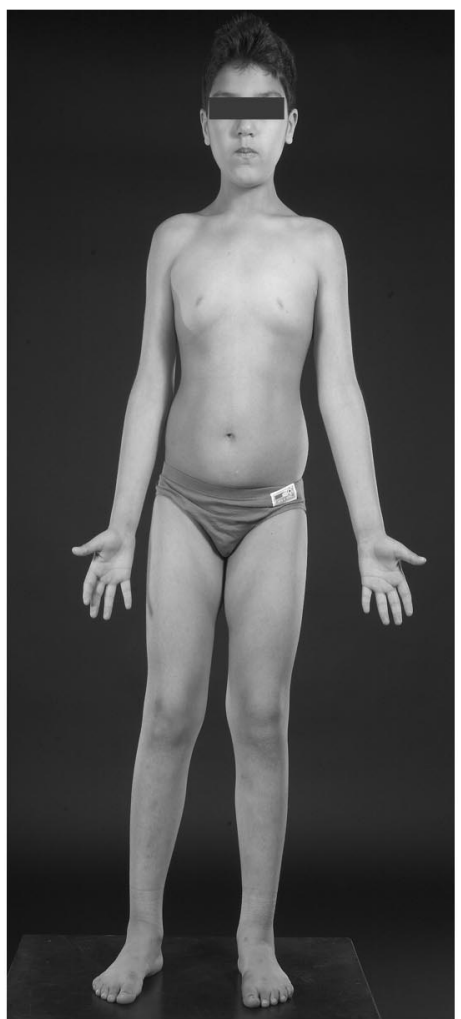

$7 \mathrm{yr}$ old weighing $32 \mathrm{~kg}$

FIG. 1. Effects of recombinant human leptin treatment in a child with leptin deficiency.

Leptin administration permitted progression of appropriately timed pubertal development in the single child of appropriate age and did not cause the early onset of puberty in the younger children (Farooqi et al., 2002). Free thyroxine and thyroid-stimulating hormone (TSH) levels, although in the normal range before treatment, consistently increased at the earliest post-treatment time point and subsequently stabilized at this elevated level (Farooqi et al., 2002). These findings are consistent with evidence from animal models that leptin influences thyrotropin-releasing hormone (TRH) release from the hypothalamus (Legradi et al., 1997; Nillni et al., 2000; Harris et al., 2001) and from studies illustrating the effect of leptin deficiency on TSH pulsatility in humans (Mantzoros et al., 2001).

Throughout the trial of leptin administration, weight loss continued in all subjects, albeit with refractory periods that were overcome by increases in leptin dose (Farooqi et al., 2002). The families in the United Kingdom harbour a 
mutation that leads to a prematurely truncated form of leptin; thus, wild-type (WT) leptin is a novel antigen to them. Thus, all subjects developed antileptin antibodies after $\approx 6$ weeks of leptin therapy, which interfered with interpretation of serum leptin levels and, in some cases, were capable of neutralising leptin in a bioassay (Farooqi et al., 2002). These antibodies are the likely cause of refractory periods that occur during therapy. The fluctuating nature of the antibodies probably reflects the complicating factor that leptin deficiency is itself an immunodeficient state (Lord et al., 1998; Matarese, 2000). Leptin administration leads to a change from the secretion of predominantly Th2 to Th1 cytokines, which may directly influence antibody production. Thus far, we have been able to regain control of weight loss by increasing the dose of leptin.

\section{Does a Heterozygous Phenotype Exist?}

The major question with respect to the potential therapeutic use of leptin in more-common forms of obesity relates to the shape of the leptin dose/response curve. We have shown clearly that at the lower end of plasma leptin levels, raising leptin levels from undetectable to detectable has profound effects on appetite and weight (Farooqi et al., 2002). Heymsfield and coworkers (1999) administered supraphysiological doses (i.e., $0.1-0.3 \mathrm{mg} / \mathrm{kg}$ body weight) of leptin to obese subjects for 28 weeks. On average, subjects lost significant weight, but the extent of weight loss and the intersubject variability has led many to conclude that the leptin resistance of common obesity cannot be usefully overcome by leptin supplementation, at least when administered peripherally. However, on scientific rather than pragmatic grounds, it is of interest that there was a significant effect on weight, suggesting that plasma leptin can continue to have a dose/response effect on energy homeostasis across a wide plasma concentration range.

To test this hypothesis, we studied the heterozygous relatives of our leptin-deficient subjects. Serum leptin levels in the heterozygous subjects were found to be significantly lower than expected for \% body fat and they had a higher prevalence of obesity than seen in a control population of similar age, sex, and ethnicity (Farooqi et al., 2001). Additionally, \% body fat was higher than predicted from height and weight of the heterozygous subjects, compared to control subjects of the same ethnicity (Farooqi et al., 2001). These findings closely parallel those in heterozygous $o b /+$ and $d b /+$ mice (Coleman, 1979; Chung et al., 1998). These data provide further support for the possibility that leptin can produce a graded response in terms of body composition across a broad range of plasma concentrations.

All heterozygous subjects had normal thyroid function and appropriate gonadotropins, normal development of secondary sexual characteristics, and normal menstrual cycles and fertility, suggesting that low leptin levels are 
sufficient to preserve these functions (Farooqi et al., 2001). This is consistent with the data of Ioffe and colleagues, who demonstrated that several of the neuroendocrine features associated with leptin deficiency were abolished in low-level leptin transgenic mice, which were fertile with normal corticosterone levels (Ioffe et al., 1998). However, these low-level leptin transgenic mice still exhibited abnormal thermoregulation in response to cold exposure and had mildly elevated plasma insulin concentrations, suggesting that different thresholds exist for the various biological responses elicited by changes in serum leptin concentration and that these could be reversed by leptin administration (Ioffe et al., 1998).

Our findings in the heterozygous individuals have implications for treating common forms of obesity. While serum leptin concentrations correlate positively with fat mass, considerable interindividual variation exists at any particular fat mass. Leptin is inappropriately low in some obese individuals. The relative hypoleptinemia in these subjects may be contributing actively to their obesity and may be responsive to leptin therapy (Ravussin et al., 1997). Heymsfield and colleagues (1999) found no relationship between baseline plasma leptin levels and therapeutic response. However, study subjects were not preselected for relative hypoleptinemia. A therapeutic trial in a subgroup of subjects selected for disproportionately low circulating leptin levels would be of great interest.

\section{Leptin Receptor Deficiency}

A mutation in the leptin receptor has been reported in one consanguineous family with three affected subjects (Clement et al., 1998). Affected individuals were found to be homozygous for a mutation that truncates the receptor before the transmembrane domain. The mutant receptor ectodomain is shed from cells and circulates bound to leptin. The phenotype has similarities to leptin deficiency. Leptin receptor-deficient subjects were of normal birthweight but exhibited rapid weight gain in the first few months of life, with severe hyperphagia and aggressive behaviour when food was denied (Clement et al., 1998). Basal temperature and resting metabolic rate were normal, cortisol levels were in the normal range, and all individuals were normoglycaemic, with mildly elevated plasma insulin similar to leptin-deficient subjects. Leptin receptor-deficient subjects had some unique neuroendocrine features not seen with leptin deficiency. Evidence of mild growth retardation in early childhood, with impaired basal and stimulated GH secretion and decreased insulin-like growth factor (IGF)-1 and IGF-binding protein (BP)3 levels, alongside features of hypothalamic hypothyroidism in these subjects, suggest that loss of the leptin receptor results in a more-severe neuroendocrine phenotype than loss of leptin itself (Clement et al., 1998). The most-likely explanation for this is that the leptin 
receptor has some constitutive ligand-independent activity that is lost when the leptin receptor is absent but retained in leptin deficiency.

\section{Pro-opiomelanocortin}

Two unrelated obese German children have been reported with homozygous or compound heterozygous mutations in pro-opiomelanocortin (POMC) (Krude et al., 1998). Both children were hyperphagic and developed early-onset obesity, presumably due to impaired melanocortin signaling in the hypothalamus (Krude et al., 1998). Presentation was in neonatal life, with adrenal crisis due to isolated corticotrophin $(\mathrm{ACTH})$ deficiency. (POMC is a precursor of ACTH in the pituitary.) The children had pale skin and red hair from the lack of MSH function at MC1Rs in the skin (Krude et al., 1998). Three additional subjects with homozygous or compound heterozygous complete loss-of-function mutations of the POMC gene have been described (Krude and Gruters, 2000). Recently, several groups have identified a heterozygous missense mutation (Arg236Gly) in POMC that disrupts the dibasic amino acid processing site between $\beta$-MSH and $\beta$-endorphin (Echwald et al., 1999; Del Giudice, 2001a; Challis et al., 2002). This results in an aberrant $\beta$-MSH/ $\beta$-endorphin fusion peptide, which binds to MC4R with an affinity identical to that of $\alpha$ - and $\beta$-MSH but has a markedly reduced ability to activate the receptor (Challis et al., 2002). Therefore, this cleavage site mutation in POMC may confer susceptibility to obesity through a novel molecular mechanism. Mutations affecting this processing site have been reported in obese children from several different populations and therefore may be a relatively common contributor to early-onset obesity.

\section{Prohormone Convertase 1 Deficiency}

Further evidence for the role of the melanocortin system in human body weight regulation comes from the description of a 47-year-old woman with severe childhood obesity, abnormal glucose homeostasis, very low plasma insulin, but elevated levels of proinsulin, hypogonadotropic hypogonadism, and hypocortisolaemia associated with increased levels of POMC (Jackson et al., 1997). She was found to be a compound heterozygote for mutations in prohormone convertase 1 ( $\mathrm{PC} 1$ ), which cleaves prohormones at pairs of basic amino acids, leaving C-terminal basic residues that are excised by carboxypeptidase $\mathrm{E}$ (CPE) (Jackson et al., 1997). We recently identified a child with severe earlyonset obesity who was compound heterozygote for complete loss-of-function mutations in PC1 (Jackson et al., 2003). Although inability to cleave POMC is a likely mechanism for obesity in these patients, $\mathrm{PC} 1$ cleaves a number of other neuropeptides in the hypothalamus, including glucagon-like-peptide 1, which may influence feeding behaviour. The phenotype of these subjects is very similar 
to that of the CPE-deficient fat/fat mouse (Naggert et al., 1995), implying that this part of the pathway may be important in controlling body weight in humans. To date, however, no humans with CPE defects have been described.

\section{Human MC4R Deficiency}

Of the five known melanocortin receptors, MC4R has been most-closely linked to control of energy balance in rodents (Yeo et al., 2000). Mice homozygous for a deleted MC4R become severely obese; heterozygotes have body weights intermediate between WT and homozygote null animals (Huszar et al., 1997). In 1998, two groups reported heterozygous MC4R mutations in humans that were associated with dominantly inherited obesity (Vaisse et al., 1998; Yeo et al., 1998). Since then, heterozygous mutations in MC4R have been reported in obese humans from various ethnic groups (Hinney et al., 1999; Farooqi et al., 2000; Vaisse et al., 2000).

We have studied over 500 severely obese probands and found that $\approx 5-6 \%$ have pathogenic MC4R mutations that are nonconservative in nature, not found in control subjects from the background population, and that co-segregate with obesity in families (Farooqi et al., 2003). MC4R deficiency represents the most-commonly known monogenic cause of human obesity. Some studies have observed a lower prevalence, which may be explained by the differing prevalence in certain ethnic groups. However, it is more likely to reflect the later onset and reduced severity of obesity of the subjects in these studies (Jacobson et al., 2002). While we found a $100 \%$ penetrance of early-onset obesity in heterozygous probands, others have described obligate carriers who were not obese (Vaisse et al., 2000). Given the large number of potential influences on body weight, it perhaps is not surprising that both genetic and environmental modifiers will have important effects in some pedigrees. Indeed, we have now studied six families in which the probands were homozygotes. In all of these, the homozygotes were more obese than the heterozygotes (Farooqi et al., 2003). Interestingly, in these families, some heterozygous carriers were not obese. This may reflect ethnicspecific effects, as all these families were of Indo origin. Taking into account all these observations, co-dominance, with modulation of expressivity and penetrance of the phenotype, is the most-appropriate descriptor for the mode of inheritance. This finding is supported by the pattern of inheritance of obesity seen in heterozygous and homozygous MC4R knockout (KO) mice (Huszar et al., 1997).

We now have studied over 70 MC4R mutant carriers in our Clinical Research Facility. In addition to increased fat mass, MC4R mutant subjects have increased lean mass that is not seen in leptin deficiency (Farooqi et al., 2003). Linear growth of these subjects is striking, with affected children having a height standard deviation score (SDS) of +2 , compared to population standards (mean 
height SDS of other obese children in our cohort $=+0.5$ ) (Farooqi et al., 2003). MC4R-deficient subjects also have higher levels of fasting insulin than age, sex, and BMI SDS-matched children (Farooqi et al., 2003). The accelerated linear growth and disproportionate early hyperinsulinaemia are consistent with observations in the MC4R KO mouse (Fan et al., 2000).

Affected subjects are objectively hyperphagic but not as severely as seen with leptin deficiency (Farooqi et al., 2003). Of particular note is the finding that the severity of receptor dysfunction seen in in vitro assays can predict the amount of food ingested at a test meal by the subject harbouring that particular mutation (Figure 2). One notable feature of this syndrome is that the severity of many of the phenotypic features appears to partially ameliorate with time. Thus, obese adult mutation carriers report less-intense feelings of hunger and are less hyperinsulinaemic than children with the same mutation (I.S. Farooqi and S. O'Rahilly, personal observations). We have studied in detail the signaling properties of many of these mutant receptors. This information should help advance the understanding of structure/function relationships within the receptor (Yeo et al., 2003). Importantly, we have been unable to discover evidence for dominant negativity associated with these mutants, which suggests that MC4R mutations are more likely to result in a phenotype through haploinsufficiency (Yeo et al., 2003).

MC4R mutations appear to be the most-common monogenic cause of obesity thus far described in humans. Maintenance of this reasonably high disease frequency is likely to be due partly to the fact that obesity is expressed in heterozygotes and no evidence exists of any apparent effect of the mutations on reproductive function.

\section{Other Possible Monogenic Syndromes}

Identification of a leptin-regulated melanocortin pathway has provided a molecular and neuroanatomical link between peripheral signals and central nervous system (CNS) circuits but leaves open the question of how these melanocortin signals produce downstream effects on appetite, energy expenditure, and neuroendocrine function. Mutations in a number of other genes have been found in association with severe obesity in a small number of individuals; however, the significance of these findings often remains unclear.

Two groups have found missense mutations in the cocaine- and amphetamine-regulated transcript (CART), a neuropeptide implicated in the control of feeding behaviour in rodents. We identified a Ser66Thr mutation in heterozygous

form in two unrelated U.K. probands. However, this did not co-segregate with obesity in family studies (Challis et al., 2000). In an Italian study, the Leu34Phe CART mutation was identified in the heterozygous state in a 10 -year-old obese 

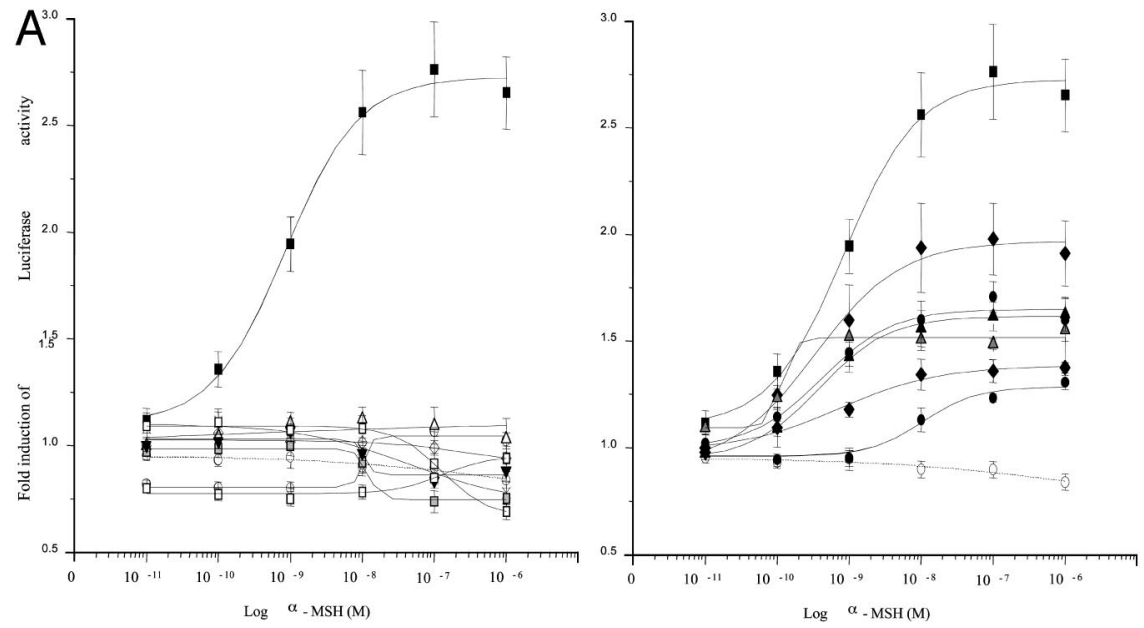

B

Mean ad libitum energy intake (kcal/kg lean mass)

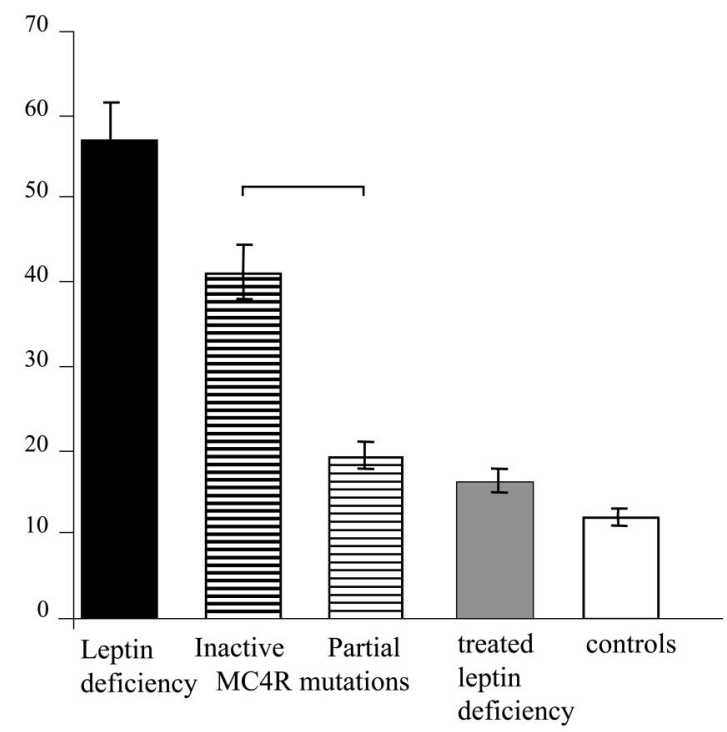

FIG. 2. Genotype-phenotype correlations in human melanocortin 4 receptor (MC4R) deficiency. (A) Cyclic adenosine monophosphate (cAMP) response to alpha-melanocyte-stimulating hormone $(\alpha-\mathrm{MSH})$ in transiently transfected human embryonic kidney (HEK)293 cells for mutant MC4Rs, indicating complete (left panel) or partial (right panel) loss of function in vitro. (B) Ad libitum food intake at an 18-megajoule (MJ) test meal for leptin-deficient subjects and for MC4R-deficient subjects with complete/partial loss-of-function mutations. 
boy and a number of obese family members but no functional data were provided (del Giudice et al., 2001b).

Holder and colleagues (2000) studied a girl with early-onset obesity and a balanced translocation between $1 \mathrm{p} 22.1$ and 6q16.2. The child displayed an aggressive, voracious appetite. The obesity was thought to be due to increased energy intake, as measured energy expenditure was normal. The translocation did not appear to affect any transcription unit on 1p but it disrupted the SIM1 gene on 6q (Holder et al., 2000). The Drosophila single-minded (sim) gene is a regulator of fruit fly neurogenesis. In the mouse, Sim1 is expressed in the developing kidney and CNS and is essential for formation of the supraoptic and paraventricular (PVN) nuclei, which express the MC4R (Michaud et al., 2001). It thus could be hypothesized that haploinsufficiency of SIM1, possibly acting upstream or downstream of MC4R in the PVN, was responsible for severe obesity in this patient.

It is of note that in all the genetic syndromes thus far described, the major physiological perturbance appears to be in appetite and energy intake. One possible exception is the description of three German subjects with mutations in the $\mathrm{N}$ terminus of the nuclear hormone receptor peroxisome proliferator-activated receptor gamma (PPAR $\gamma)$, an important determinant of adipogenesis (Ristow et al., 1998). Receptors containing this mutation are more-powerful inducers of adipogenesis when transfected into cultured cells. Unfortunately, however, no information is available regarding the co-segregation of this mutation with obesity in pedigrees. Since this mutation appears to be unique to the original population, it has not been possible to test this issue in independent families.

\section{Summary}

Several monogenic forms of human obesity have been identified by searching for mutations homologous to those causing obesity in mice. Although such monogenic obesity syndromes are rare, the successful use of murine models to study human obesity indicates that substantial homology exists across mammalian species in the functional organisation of the weight regulatory system. More importantly, identification of molecules that control food intake has generated new targets for drug development in the treatment of obesity and related disorders. These considerations indicate that an expanded ability to diagnose the pathophysiological basis of human obesity will have direct applications to its treatment. A more-detailed understanding of the molecular pathogenesis of human obesity ultimately may guide treatment of affected individuals. 


\section{REFERENCES}

Anand BK, Brobeck JR 1951 Hypothalamic control of food intake in rats and cats. Yale J Biol Med 24:123-146

Barsh GS, Farooqi IS, O'Rahilly S 2000 Genetics of body-weight regulation. Nature 404:644-651 Bray GA, York DA 1971 Genetically transmitted obesity in rodents. Physiol Rev 51:598-646

Challis BG YG, Farooqi IS, Luan J, Aminian S, Halsall DJ, Keogh JM, Wareham NJ, O'Rahilly S 2000 The CART gene and human obesity: mutational analysis and population genetics. Diabetes 49:872-875

Challis BG, Pritchard LE, Creemers JW, Delplanque J, Keogh JM, Luan J, Wareham NJ, Yeo GS, Bhattacharyya S, Froguel P, White A, Farooqi IS, O'Rahilly S 2002 A missense mutation disrupting a dibasic prohormone processing site in pro-opiomelanocortin (POMC) increases susceptibility to early-onset obesity through a novel molecular mechanism. Hum Mol Genet 11:1997-2004

Chen Y, Hu C, Hsu CK, Zhang Q, Bi C, Asnicar M, Hsiung HM, Fox N, Slieker LJ, Yang DD, Heiman ML, Shi Y 2002 Targeted disruption of the melanin-concentrating hormone receptor-1 results in hyperphagia and resistance to diet-induced obesity. Endocrinology 143:2469-2477

Chung WK, Belfi K, Chua M, Wiley J, Mackintosh R, Nicolson M, Boozer CN, Leibel RL 1998 Heterozygosity for Lep(ob) or Lep(rdb) affects body composition and leptin homeostasis in adult mice. Am J Physiol 274:R985-R990

Clement K, Vaisse C, Lahlou N, Cabrol S, Pelloux V, Cassuto D, Gourmelen M, Dina C, Chambaz J, Lacorte JM, Basdevant A, Bougneres P, Lebouc Y, Froguel P, Guy-Grand B 1998 A mutation in the human leptin receptor gene causes obesity and pituitary dysfunction. Nature 392:398-401

Coleman DL 1973 Effects of parabiosis of obese with diabetes and normal mice. Diabetologia 9:294-298

Coleman DL 1979 Obesity genes: beneficial effects in heterozygous mice. Science 203:663-665

Del Giudice EM CG, Santoro N, et al. 2001a Molecular screening of the proopiomelanocortin (POMC) gene in Italian obese children: report of three new mutations. Intl J Obes Relat Metab Disord 25:61-67

del Giudice EM, Santoro N, Cirillo G, D'Urso L, Di Toro R, Perrone L 2001b Mutational screening of the CART gene in obese children: identifying a mutation (Leu34Phe) associated with reduced resting energy expenditure and cosegregating with obesity phenotype in a large family. Diabetes 50:2157-2160

Dubuc PU 1977 Basal corticosterone levels of young ob/ob mice. Horm Metab Res 9:95-97

Dubuc PU, Carlisle HJ 1988 Food restriction normalizes somatic growth and diabetes in adrenalectomized ob/ob mice. Am J Physiol 255:R787-R793

Echwald SM, Sorensen TI, Andersen T, Tybjaerg-Hansen A, Clausen JO, Pedersen O 1999 Mutational analysis of the proopiomelanocortin gene in Caucasians with early onset obesity. Intl J Obes Relat Metab Disord 23:293-298

Fan W, Dinulescu DM, Butler AA, Zhou J, Marks DL, Cone RD 2000 The central melanocortin system can directly regulate serum insulin levels. Endocrinology 141:3072-3079

Farooqi IS, Jebb SA, Langmack G, Lawrence E, Cheetham CH, Prentice AM, Hughes IA, McCamish MA, O'Rahilly S 1999 Effects of recombinant leptin therapy in a child with congenital leptin deficiency. N Engl J Med 341:879-884

Farooqi IS, Yeo GS, Keogh JM, Aminian S, Jebb SA, Butler G, Cheetham T, O'Rahilly S 2000 Dominant and recessive inheritance of morbid obesity associated with melanocortin 4 receptor deficiency. J Clin Invest 106:271-279 
Farooqi IS, Keogh JM, Kamath S, Jones S, Gibson WT, Trussell R, Jebb SA, Lip GY, O'Rahilly S 2001 Partial leptin deficiency and human adiposity. Nature 414:34-35

Farooqi IS, Matarese G, Lord GM, Keogh JM, Lawrence E, Agwu C, Sanna V, Jebb SA, Perna F, Fontana S, Lechler RI, DePaoli AM, O'Rahilly S 2002 Beneficial effects of leptin on obesity, $\mathrm{T}$ cell hyporesponsiveness, and neuroendocrine/metabolic dysfunction of human congenital leptin deficiency. J Clin Invest 110:1093-1103

Farooqi IS, Keogh JM, Yeo GS, Lank EJ, Cheetham T, O'Rahilly S 2003 Clinical spectrum of obesity and mutations in the melanocortin 4 receptor gene. N Engl J Med 348:1085-1095

Harris M, Aschkenasi C, Elias CF, Chandrankunnel A, Nillni EA, Bjoorbaek C, Elmquist JK, Flier JS, Hollenberg AN 2001 Transcriptional regulation of the thyrotropin-releasing hormone gene by leptin and melanocortin signaling. J Clin Invest 107:111-120

Hervey GR 1959 The effects of lesions in the hypothalamus in parabiotic rats. J Physiol London 145:336

Hetherington AW, Ranson SW 1940 Hypothalamic lesions and adiposity in the rat. Anat Rec 78:149-172

Heymsfield SB, Greenberg AS, Fujioka K, Dixon RM, Kushner R, Hunt T, Lubina JA, Patane J, Self B, Hunt P, McCamish M 1999 Recombinant leptin for weight loss in obese and lean adults: a randomized, controlled, dose-escalation trial. JAMA 282:1568-1575

Hinney A, Schmidt A, Nottebom K, Heibult O, Becker I, Ziegler A, Gerber G, Sina M, Gorg T, Mayer H, Siegfried W, Fichter M, Remschmidt H, Hebebrand J 1999 Several mutations in the melanocortin-4 receptor gene including a nonsense and a frameshift mutation associated with dominantly inherited obesity in humans. J Clin Endocrinol Metab 84:14831486

Holder JL Jr, Butte NF, Zinn AR 2000 Profound obesity associated with a balanced translocation that disrupts the SIM1 gene. Hum Mol Genet 9:101-108

Huszar D, Lynch CA, Fairchild-Huntress V, Dunmore JH, Fang Q, Berkemeier LR, Gu W, Kesterson RA, Boston BA, Cone RD, Smith FJ, Campfield LA, Burn P, Lee F 1997 Targeted disruption of the melanocortin-4 receptor results in obesity in mice. Cell 88:131-141

Ioffe E, Moon B, Connolly E, Friedman JM 1998 Abnormal regulation of the leptin gene in the pathogenesis of obesity. Proc Natl Acad Sci USA 95:11852-11857

Jackson RS, Creemers JW, Ohagi S, Raffin-Sanson ML, Sanders L, Montague CT, Hutton JC, O'Rahilly S 1997 Obesity and impaired prohormone processing associated with mutations in the human prohormone convertase 1 gene [see comments]. Nature Genet 16:303-306

Jackson RS, Creemers JW, Farooqi IS, Raffin-Sanson ML, Varro A, Dockray GJ, Holst JJ, Brubaker PL, Corvol P, Polonsky KS, Ostrega D, Becker KL, Bertagna X, Hutton JC, White A, Dattani MT, Hussain K, Middleton SJ, Nicole TM, Milla PJ, Lindley KJ, O'Rahilly S 2003 Small-intestinal dysfunction accompanies the complex endocrinopathy of human proprotein convertase 1 deficiency. J Clin Invest 112(10):1550-1560

Jacobson P, Ukkola O, Rankinen T, Snyder EE, Leon AS, Rao DC, Skinner JS, Wilmore JH, Lonn L, Cowan GS Jr, Sjostrom L, Bouchard C 2002 Melanocortin 4 receptor sequence variations are seldom a cause of human obesity: the Swedish Obese Subjects, the HERITAGE Family Study, and a Memphis cohort. J Clin Endocrinol Metab 87:4442-4446

Kennedy GC 1953 The role of depot fat in the hypothalamic control of food intake in the rat. Proc R Soc London 140:578-596

Krude H, Gruters A 2000 Implications of proopiomelanocortin (POMC) mutations in humans: the POMC deficiency syndrome. Trends Endocrinol Metab 11:15-22

Krude H, Biebermann H, Luck W, Horn R, Brabant G, Gruters A 1998 Severe early-onset obesity, adrenal insufficiency and red hair pigmentation caused by POMC mutations in humans. Nature Genet 19:155-157 
Legradi G, Emerson CH, Ahima RS, Flier JS, Lechan RM 1997 Leptin prevents fasting-induced suppression of prothyrotropin-releasing hormone messenger ribonucleic acid in neurons of the hypothalamic paraventricular nucleus. Endocrinology 138:2569-2576

Leibel RL, Chung WK, Chua SC Jr 1997 The molecular genetics of rodent single gene obesities. J Biol Chem 272:31937-31940

Lord GM, Matarese G, Howard JK, Baker RJ, Bloom SR, Lechler RI 1998 Leptin modulates the T-cell immune response and reverses starvation-induced immunosuppression. Nature 394: 897-901

Mantzoros CS, Ozata M, Negrao AB, Suchard MA, Ziotopoulou M, Caglayan S, Elashoff RM, Cogswell RJ, Negro P, Liberty V, Wong ML, Veldhuis J, Ozdemir IC, Gold PW, Flier JS, Licinio J 2001 Synchronicity of frequently sampled thyrotropin (TSH) and leptin concentrations in healthy adults and leptin-deficient subjects: evidence for possible partial TSH regulation by leptin in humans. J Clin Endocrinol Metab 86:3284-3291

Matarese G 2000 Leptin and the immune system: how nutritional status influences the immune response. Eur Cytokine Netw 11:7-14

Michaud JL, Boucher F, Melnyk A, Gauthier F, Goshu E, Levy E, Mitchell GA, Himms-Hagen J, Fan CM 2001 Sim1 haploinsufficiency causes hyperphagia, obesity and reduction of the paraventricular nucleus of the hypothalamus. Hum Mol Genet 10:1465-1473

Montague CT, Farooqi IS, Whitehead JP, Soos MA, Rau H, Wareham NJ, Sewter CP, Digby JE, Mohammed SN, Hurst JA, Cheetham CH, Earley AR, Barnett AH, Prins JB, O'Rahilly S 1997 Congenital leptin deficiency is associated with severe early-onset obesity in humans. Nature 387:903-908

Naggert JK, Fricker LD, Varlamov O, Nishina PM, Rouille Y, Steiner DF, Carroll RJ, Paigen BJ, Leiter EH 1995 Hyperproinsulinaemia in obese fat/fat mice associated with a carboxypeptidase E mutation which reduces enzyme activity. Nature Genet 10:135-142

Nillni EA, Vaslet C, Harris M, Hollenberg A, Bjorbak C, Flier JS 2000 Leptin regulates prothyrotropin-releasing hormone biosynthesis. Evidence for direct and indirect pathways. J Biol Chem 275:36124-36133

Ozata M, Ozdemir IC, Licinio J 1999 Human leptin deficiency caused by a missense mutation: multiple endocrine defects, decreased sympathetic tone, and immune system dysfunction indicate new targets for leptin action, greater central than peripheral resistance to the effects of leptin, and spontaneous correction of leptin-mediated defects. J Clin Endocrinol Metab 84:3686-3695

Rau H, Reaves BJ, O'Rahilly S, Whitehead JP 1999 Truncated human leptin (delta133) associated with extreme obesity undergoes proteasomal degradation after defective intracellular transport. Endocrinology 140:1718-1723

Ravussin E, Pratley RE, Maffei M, Wang H, Friedman JM, Bennett PH, Bogardus C 1997 Relatively low plasma leptin concentrations precede weight gain in Pima Indians. Nature Med 3:238-240

Ristow M, Muller-Wieland D, Pfeiffer A, Krone W, Kahn CR 1998 Obesity associated with a mutation in a genetic regulator of adipocyte differentiation. N Engl J Med 339:953-959

Rosenbaum M, Murphy EM, Heymsfield SB, Matthews DE, Leibel RL 2002 Low dose leptin administration reverses effects of sustained weight-reduction on energy expenditure and circulating concentrations of thyroid hormones. J Clin Endocrinol Metab 87:2391

Shimada M, Tritos NA, Lowell BB, Flier JS, Maratos-Flier E 1998 Mice lacking melaninconcentrating hormone are hypophagic and lean. Nature 396:670-674

Strobel A, Issad T, Camoin L, Ozata M, Strosberg AD 1998 A leptin missense mutation associated with hypogonadism and morbid obesity. Nature Genet 18:213-215

Trayhurn P, Thurlby PL, James WPT 1977 Thermogenic defect in pre-obese ob/ob mice. Nature 266:60-62 
Vaisse C, Clement K, Guy-Grand B, Froguel P 1998 A frameshift mutation in human MC4R is associated with a dominant form of obesity [letter]. Nature Genet 20:113-114

Vaisse C, Clement K, Durand E, Hercberg S, Guy-Grand B, Froguel P 2000 Melanocortin-4 receptor mutations are a frequent and heterogeneous cause of morbid obesity. J Clin Invest 106:253-262

Yeo GS, Farooqi IS, Aminian S, Halsall DJ, Stanhope RG, O'Rahilly S 1998 A frameshift mutation in MC4R associated with dominantly inherited human obesity. Nature Genet 20:111-112

Yeo GS, Farooqi IS, Challis BG, Jackson RS, O'Rahilly S 2000 The role of melanocortin signalling in the control of body weight: evidence from human and murine genetic models. Q J Med 93:7-14

Yeo GS, Lank EJ, Farooqi IS, Keogh J, Challis BG, O'Rahilly S 2003 Mutations in the human melanocortin-4 receptor gene associated with severe familial obesity disrupts receptor function through multiple molecular mechanisms. Hum Mol Genet 12:561-574 